\author{
Alan Titley \\ University College \\ Cork, Ireland
}

\title{
RUSSIANS IN THE WESTERN ISLES
}

\section{Introduction}

The subtitle of this conference is "Celts and Slavs in south-eastern Europe", so in order to give the proceedings some balance, I have decided to talk about Slavs and Celts in north-western Europe instead. By northwestern Europe I do not mean either Iceland or Tory Island, but rather the outer reaches of the Celtic fringe in Scotland; and as the Scottish element in Celto-Slavic studies has been so far somewhat shy I have taken it upon myself to speak for them in the full knowledge that this may have unsavoury repercussions in later years in the backstreets of Glasgow, or in an illicit shebeen in the Butt of Lewis. More particularly I want to address the presence of east Europeans, most specifically Russians, in Scottish fiction in recent years.

For the purposes of this paper, I am going to refer to Scottish Gaelic as Scottish, and to Irish Gaelic as Irish. Historically, both of them were known in English as "Irish", as in The Act of the Privy Council of $10^{\text {th }}$ December 1616 which sought to establish an English School in every parish in Scotland, and required that

The vulgar Inglishe tongue be universallie plantit, and the Irish language, whilk is one of the cheif and principall causis of the continewance of barbarities and incivilitie amongis the inhabitantis... may be abolisheit and removit.

or nearly a hundred years later Daniel Defoe, when he was not composing unlikely narratives, acted as a spy for the English government in Scotland and expressed the hope that "in a few Years, Ignorance, Popery and the Irish language will be utterly extirpated; and in their stead, Virtue, Loyalty and Industry, will take place". But as the Irish long ago gave up any kind of imperial ambitions, there is sufficient evidence and support that we can refer to their Gaelic, as simply Scottish, which is what it was also called for a period, before that term was appropriated by the English-speakers of the lowlands. 


\section{Irish and Scottish: divergence in writing and literacy}

Whereas Irish and Scottish (again using these terms as I have described them) share a common history and culture and sympathy, their histories as written and as literate languages do diverge. There was certainly a great literacy in Scottish, but maybe surprisingly their invention of the novel happened around the same time, give or take a few years. Whereas literacy in Irish had always been confined to a small minority of aristocrats and scholars until the late nineteenth century - it has been estimated by Professor David Greene, that of 70,000 speakers of Irish in Donegal in 1890, only $1 \%$ could read it - literacy in Scottish was remarkably rich. You cannot have a novel-reading public without literacy. The Scottish Presbyterian culture, with its emphasis on the word as the voice of God, pursued literacy with a vigour that matched their pursuance of witches.

Scottish divines had not read Derrida or Foucault and never imagined that the solid word could melt into thin slipperiness. As a result, the Word of God was taught without ambiguity throughout the Scottish-speaking areas, even if God himself didn't always agree. God certainly should have had some problems with the closing of playgrounds on the Sabbath, but maybe even in Heaven you can only play six days a week. On the island of Harris, public toilets are closed on a Sunday, which simply means that normal Christians suffer the same pain as their cows, whom, as the Bible decrees, Book of Bovines, chapter whatever, verse you know what, should not be milked on the Sabbath. In Ratharsaidh, birthplace of the great poet Somhairle MacGill-eain, and whose woods are dark and deep, it was truly said that even if Jesus affirmed that it was right to take your donkey out of a hole on the Sabbath, the islanders didn't think any the better of him because of that.

The Scots learned literacy because it was required that they learned to read the Bible, even if they didn't have to think about it. But as soon as they could read in Scottish, they could also read in English, as the two orthographic systems are only a few hundred years apart. Readers of Scottish quickly discovered that while there were great stories in the Bible like the story of Tamar and Judah in the Book of Genesis, or Lot and his daughters, there were similar contemporary stories in English in the popular press. And in the battle between modernity and tradition, modernity always wins.

So while there was a much greater tradition of literacy in Scottish rather than in Irish, their readers did not have a great choice of what they could read in the late nineteenth century. Reading in Scottish meant the 
Bible, and the Bible again, and after that again the Bible. Reading in Irish meant the folk tale and the saga and the bit of local gabble gossip.

In both cultures the novel was explosive. The novel is one of the greatest inventions of the human spirit. The novel breaks up traditional narrative, and destroys the old formulas of writing. At its best the novel tells it as it is, and at least it tells it as it might be. Traditional storytelling is formulaic, and the formula decides the narrative and the vocabulary. The novel is anarchic and revolutionary. The novel is bare of the alliterative, syntactical rhythmical unity of verse, and equally free of the predictability of the romantic or the folk tale.

\section{The early Scottish novel}

The early Scottish novel was therefore revolutionary in breaking from the formula. Not surprisingly, it was not so revolutionary in breaking from the mould of the Victorian novel. The very first Scottish story that we can affirm as being published as a novel is Dùn Alainn, by Iain MacCormaig, published in 1912, although in point of subject matter and treatment it could have been written any time in the previous hundred years.

It is not a novel that is likely to be re-read with any great enthusiasm, or re-published with the expectation of massive profits. On the other hand, it is a mine of valuable insights into the possibilities of co-incidence. The hero, if we can call him such, is dispossessed of his inheritance of a big estate and some peasant slaves, and is forced to flee to New Zealand, always a refuge for hen killers, sheep stealers, and aristocratic Scots whom revenge had not yet caught up with. Because he is a canny Scot, he makes a fortune in some dubious mining venture. He returns to Britain, and lo and behold, lodges in a house in London. Just as chance would have it, or even the lack of imagination of the author, he happens to hear one of the servant girls singing a highland song. And while he recognises the song as an Irish person would recognise "Willy McBride" even if he didn't want to, he does not realise that this is the lover that he has left behind him.

Now London is a big city, and Scots are few. And the chances of a returning Scottish emigrant meeting his former sweetheart in the first lodging house he happened to doss into on the very day that he returns is as remote as Ireland winning The World Cup. But yet, this is the Scottish novel, the bairn of the language itself, and of the forms available without. But if Charles Dickens and Pádraic Ó Conaire can get away with coinci- 
dences most improbable, there is no reason why a lesser novelist by multiples of google numbers yet unimagined should not do so also. Needless to say, there is a happy ending, and happy endings were so unrealistic in Scottish highland life, as to make this novel a work of science fiction.

There have been about 300 novels in Irish since the first Irish novel one hundred and five years ago. The Scottish haul is about one tenth of that. Less than thirty, depending on what you call a novel, and I am very catholic in my interpretation, despite protestations to the contrary. The Irish novel was born at a time when reading as a pastime grew for pleasure; the Scottish novel was born at exactly the same time when reading was forcibly popularised as a means of escaping from pleasure. The Bible is a great collection of Jewish stories and poems, but unfortunately tales of Jonah in the belly of the whale, and of Abraham threatening to burn his son on the altar were far more widespread than the passionate love poetry of the Song of Songs.

There was also a problem with realism. The novel is pre-eminently a realistic medium despite all the doubts and caveats we might have about whatever realism pretends to be. When John Francis Campbell, Iain Og Ile, collected his highland tales in the late nineteenth century, he did not imagine that people believed the tale of Balgam Mòr, or "Great Gulp". And when each of the tales he began started with a formulaic phrase, such as bha nighean aig Righ Eilean nam Ban a bha anabarrach brèagha 'the King of the Isle of Woman had a daughter who was exceedingly beautiful', or bha Rìgh anns an Fhraing agus phòs e, agus bha gaol mòr aige air a' Bhannrighinn 'there was once a King in France who married, and he loved the queen very much', we know we are in the presence of stock storytelling, and for all the wonder and fantasy of the folktale, it is only the expected that ever happens. In that last story about the King of France, for example, we don't expect him to get his head chopped off, which is one of the more fortunate things to happen in real life.

The novel, at least, plays lip-service to the real world, tries to tell us how things are, or were, or might be. An Irish scholar, whose name escapes me at the moment, once said that when we read the Scéalta Fiannaíochta, we learn that they were just like us. And if this is true of the Fiannaíocht, it is so much more true of the novel. What would we not give to have an Irish or Scottish novel written by an ordinary person, about ordinary things, from say, the seventeenth century? The greatest poetry and the greatest mediaeval tales do not give us that sense of plain lived life, it does not plank us plangently down in the middle of things and say: "This is what it was like!" 


\section{The Scottish autobiography}

There are some reasonably good autobiographies in Scottish, but they are by no means as numerous as the Irish ones. I have written about this before, but I would like to make one brief observation, albeit a wildly general one. In the Irish Gaeltacht autobiography, the big classics, in particular, the author will typically stay at home and live in his community throughout his life. In the Scottish autobiography, the author will typically have travelled the world, usually in the British Imperial Army or navy bringing culture and civilisation and good manners and obedience to lesser breeds outside their paws, and will return to his island or highland home at the end of his days to repent and to reminisce. There is a greater sense of change, then, in the Scottish books than the Irish ones; and this sense of change, of disruption, of the breaking of the community seems to be a common thread running through the Scottish fiction that I am talking about.

One brief example: Iain Mac a'Ghobhainn, or Iain Crichton Smith which is the name he wrote under in English, published a short but beautiful novel entitled An t-Aonaran ('The Individual', or maybe 'The Loner') in 1976. Incidentally, this was the first real novel in Scottish for fifty years! The novel is set in a town land somewhere on a Scottish Island, probably his native Lewis. Nothing much happens - which is not unusual in itself in a small rural community - except that a stranger comes to the area, pitches a tent on the outskirts of the settlement and lives there for a while. Nobody knows who he is, where he has come from, what his name is, and we never find out.

This is quite the opposite of what would happen to a visitor in a similar Irish village whose background, lineage, relations, history, political allegiance, sexual preferences and bank account would be exposed in about five minutes. But this stranger's very presence is enough to disrupt the settled life of the people. He awakens dreams in some, or longings in others, or speculation, or the possibility of roads not travelled, or of hopes unfulfilled. Just the fact that he is there creates a crisis of self-belief, even though he is a silent partner, a dumb outsider.

I mention this because a great deal of Scottish fiction deals with the disruption of community, particularly island, Gàidhealtachd community; or with a community just about holding on, or being under assault, or slowly dying, or being transformed. The community in Tormod Caimbeul's Deireadh an Fhòghair ('The End of Autumn'), published in 1979, is on its last legs, and could do with an injection of people from the outside. But more recent fiction deals with communities that have already been dis- 
rupted, that have been fractured, that are frayed and frustrated, but in which individual life is often vibrant, and personal, and risky.

\section{Russians: the disruptors of the Gàidhealtachd community}

In two of these novels, in particular, the disruptors are Russians. There is a strange irony that more than half of all Scottish novels ever have been written in the last eight years; that is to say, more imaginative non-traditional prose has been composed in a few years than in all the many centuries of Scottish writing put together, and they are largely ignored by scholars on the assumption that what is new is bad, and what is old is good. This entirely misses the point that there was a time when the medieval was modern, and the old was the height of fashion. It also conveniently forgets that modern demotic speech is far more vibrant than the ponderous classical cadences of yesteryear.

Thus, the extent and range of modern Scottish fiction may be not a sign of decline but of life and vitality. The communities of which they speak may be only communities in a geographical sense, but the individuals therein have been given a lease of life which they would never have had under the stultifying norms of imposed conformity.

The Russians, in a sense, are only an excuse. There is a kind of reality in Iain Mac Leoid's Na Klondykers ('The Klondykers'), published in 2005, insofar as Russian factory ships have been raking and farming Scottish and Irish waters for many years, and depriving Irish and Scottish fisherman of their livelihood; in much the same way as Irish factory ships have invaded West African waters and caused consternation among fishermen there. But the device is introduced to bring an element of exoticism to the story, given perceptions of the Russian character in Western stories, at least since the heyday of spy fiction of Ian Fleming's James Bond, or John le Carré's carefully crafted novels. In those days, Russians were spies, and thus secretive, manipulative, untrustworthy; nowadays they are more likely to be viewed as football oligarchs, dripping with money, or suspicious agents of a Russian government, as in the latest of Ian Rankin's detective novels Exit Music, also set in Scotland, starring dissident poets, dubious Russian diplomats, and unscrupulous businessmen. The star crook in a recently released gangster film Rockanrolla, is, what else, a Russian tycoon.

Iain Mac Leòid's novel is a lot clearer than that. He brings together a collection of local people in a Scottish village or town in the year 1989, who are either unemployed, or part-time fishermen, or who will do an- 
ything to make money this week, no matter what else might happen the week after. Anchored in the harbour, a little way out, is a Russian fish factory ship. The captain of the ship sells drugs to some of the local dealers, and the local community are willing to provide other services, including prostitution, to the Russian ship. Whatever about the truth of this, and it is largely a realistic novel, there is a football game arranged between the Russians and the local Scots, which the Scots, not surprisingly, win. This provides a vein of fantasy, unreality and of wish-fulfilment which is largely absent from the rest of the novel.

He does, however, make a real attempt at telling the back-story of some of the Russian characters. In particular he introduces two women, Helena and Natasha, who have left home to work at the fish on the ship for different reasons, both financial and personal. I have no idea what kind of research Iain MacLeòid did in investigating the background of his characters; but as we know in fiction, a drop of imagination is worth an ocean of research. And as the novel is the supreme art form which treats people from all countries at all times and in all languages as human beings first, and second, and always, there is no reason why a young man from Santiago cannot imagine an old woman from Sichuan Province in China; or that a contemporary poor woman from Polynesia cannot imagine an aristocratic gentleman from St. Petersburg living in the nineteenth century.

Helena has left partly because of money: Rinn iad barrachd airgid ann am mìos air na bàtaichean na dhèanadh iad ann am bliadhna aig an taigh 'They made more money in one month on the boats than they did in one year at home' (MacLeòid 2005: 81); but she also has been disappointed in Russian men, and although one man in particular was crazy about her, she did not fancy him: Bha aon bhalach ann a bha daonnan a' faighneachd dhi an deigheadh i a-mach comhla ris, ach cha robh i dèidheil air: cha robh $i$ cinnteach an robh e coir ri boireannaich 'There was one guy who really fancied her and was always asking her out, but she did not really like him: she wasn't sure if he treated women properly' (ib.).

While this may not be the most penetratingly profound psychology, it carries the story along. And we are happy to learn that Helena eventually finds love with one of the locals, and it is a love affair that is not described in any sloppy, stupid, sugary or incredible fashion. Unfortunately, her local lover drowns while at sea - for what is a fishing community story without a drowning - and she returns to Russia pregnant with his child. There is a very touching ending, however, when Helena returns with her son to visit his father's grave in the year 2005, an ending that is quiet and 
dignified and in contrast to much of the loud talk and boasting and criminality throughout the rest of this novel of nearly three hundred pages.

The other novel Dacha Mo Ghaol ('Dacha My Love'), published in 2005 as well, is an entirely contrasting piece of writing. The author Tormod MacGill-Eain has written four novels. They all seem to feature chancers, down-and-outs, people living on the edge, people you would not trust your last money with, or any of it. His characters talk fast, live fast, drive fast, drink fast and a lot. They curse and swear and tell jokes and make quips like out of a situation comedy. The plots may be often improbable, but the telling is vigorous. The novel works in flashes, but the flashes are illuminating. And without sparks there is no fire.

The improbability in Dacha Mo Ghaol has to do with his usual characters trying to make money on schemes that will never work. In this case, the brain behind a project wants to start an ostrich farm in South Uist. While this in itself is not entirely outlandish, apart from the fact that the ostriches would probably quickly learn to fly given the never-ending winds of the island, a more improbable scenario is that the ostrich farm would only be a front for a lap-dancing club. The chances of a lapdancing club surviving in Uist are about as great as turning the Great Blasket Island into a nudist colony given the weather, which was indeed the sub-plot of an Irish novel by Pádraig Ua Maoileoin. But the real rub is that this lap-dancing club is going to feature Russian women strutting their stuff, or doing their thing. Unfortunately, the schemer who has devised this plan has to get Russian women legally into Britain, as the presence of some exotic beauty in the Western Isles would provide fatal culture shock. In order to do this, he has to marry them off to some hard-up locals who are short of money, and willing to take a chance, if not necessarily an opportunity.

The plot concerns a tension between the footloose unemployed who will do anything to turn a buck, or in this case a few shillings, and the settled community who want to retain some semblance of the old ways, or at least a pretence to that effect. Unfortunately, the best chance of terrorising the Russians and the chancers is an elder of the church (or leader) who has already swapped the one true God for the bottle, and found the one true God wanting. Looking for a breakfast of whiskey as a starter, and also as a main course, and then for dessert, the moral guardians of the Western Isles resort to more subtle methods, like kidnapping and the unambiguous threat of murder.

Again, it is quite clear that the Russians are only there for their exoticism, for their mystery, for their danger born from the reading of James 
Bond novels. The two unemployed wasters, Daibhidh and Calum, agree to marry the Russians, even though they have never seen them before. Unfortunately, these women are straight out of the worst horrors of the western imagination, big ugly nasty bone-crushing female monsters out of the east, from whom they cringe, with some justification. It is true that in the novel the horrors and the beauties and the banalities of the real world are not turned into dreams; but on the same account, they should not be turned into nightmares. They are so awful, in all senses of that word, that one of the men faints during the wedding ceremony, a practice more often associated with women in romantic fiction.

This novel is a kind of thriller, where the plot and story takes precedence over character. There are no deep Freudian insights, but then Freud did not have too many of them himself, thinking that Viennese old ladies were emblematic of humanity and that Hitler did not mean what he said about annexing Austria and doing away with the Jews. Dacha mo Ghaol is modern Fiannaíocht, where action and talk are most supreme, and where action and talk reveal character. We study ancient and mediaeval literature because the modern age exists in its folds; but we should study the modern because it is the ancient and mediaeval made new.

The banter in Dacha Mo Ghaol is just as entertaining as anything you will find in that same Fiannaíocht, or in the modern detective novel.

"Onorach mo thòn" thuirt Calum. "Tha Tiny MacCormaig cho cam "s nach eil e direach nuair a bhios e na shineadh san leabaidh" (MacGill-Eain 2005: 20-21).

"Honourable my arse", said Calum. "Tiny McCormick is so crooked that he cannot lie straight in bed."

Of a meal - granted on an airplane - it was said: Bha an fheòil cho amh, cha mhòr nach cluinneadh tu i a' comhartaich nuair a bheireadh tu glamhach aiste (MacGill-Eain 2005: 74), 'The meat was so raw you could nearly hear it barking when you took a bite out of it.'

The intruding Russians are eventually sent on their way by a combination of threats and bribes. When peace is restored somebody says: Tha a h-uile càil mar bu ghnàth a-nis, mar a tha mi tuigsinn (MacGill-Eain 2005: 121), 'Everything is back to normal again, just as I understand it.' But, of course, it isn't. The theory that literature has no connection with real life has the advantage of the suppression of evidence. There is no easy return in the Scottish novel, there are no idylls, there is no holy previous existence of an unsullied community. We should be always grateful for the realistic novel as it is always less afraid of the boring past than of 
the dazzling present. Any examination of early literature should work on the assumption that if there were good writers then, there should be good writers now, also. In aesthetics, it is only the immediate present impact that counts, whether the work was composed or written or sculpted two thousand years or two months ago.

\section{Conclusion: Scottish fiction as repository of real speech}

The novels which I have spoken about are not the very best of Scottish fiction in recent years. But they are, what is often called, "a good read". Since modern fiction brings to life the colour of words, their taste, their tang, their immediacy, their everyday practice, even students of language can glean a lot from them as the ear of the storyteller is as finely tuned as that of the phoneticist. Colloquial Scottish is rife with idiomatic borrowings from English. In Dacha Mo Ghaol somebody says: Faigh os a chionn! which is clearly English "Get over it!". Ghabh e àite is common in folktales, as "It took place". A' faighinn air adhart can mean 'getting on' as in "How are you getting on?" and I have even heard in all seriousness $A$ bheil thu a'faireachdainn comhla ri cupa tì? which literally, really literally, word by word without irony translates as 'Do you feel like a cup of tea?' The novel is the great repository of real speech, of ordinary feelings, of human moments re-enacted in the common language of the general person.

So, if the Russians appear in Scottish, they are entirely absent from Irish. There are no Russian spies in Irish, no stereotypical silent KGB types wielding poisonous umbrellas, no ideological Communists trying to convert the West of Ireland from native Catholicism, and there are most certainly no Russian multibillionaires trying to buy up struggling League of Ireland clubs.

Maybe it is time that we introduced some of them into our fiction, whatever about our football.

Appendix:

This table presents a chronology of Scottish Gaelic novels since 1912 to the time of the conference. A few others have appeared in the meantime, but have not been considered for this discussion. 
Alan Titley:

Russians in the Western Isles

\begin{tabular}{|c|c|c|c|c|}
\hline & $\begin{array}{l}\text { Nobhail } \\
\text { Novel }\end{array}$ & $\begin{array}{l}\text { Üghdar } \\
\text { Author }\end{array}$ & $\begin{array}{l}\text { Bli- } \\
\text { adhna } \\
\text { Year }\end{array}$ & $\begin{array}{l}\text { Foilseachair } \\
\text { Publisher }\end{array}$ \\
\hline 1 & Dùn Àilean & Iain MacCormaig & 1912 & $\begin{array}{l}\text { Alasdair MacLabhruinn \& } \\
\text { a Mhic, Glaschu }\end{array}$ \\
\hline 2 & An t-Ogha Mòr & Aonghas MacDhonnchaidh & 1913 & $\begin{array}{l}\text { Alasdair MacLabhruinn \& } \\
\text { a Mhic, Glaschu }\end{array}$ \\
\hline 3 & Cailin Sgìathanach & Seumas MacLeòid & 1923 & $\begin{array}{l}\text { Volturna \& Marsland, } \\
\text { Ceann Phàdraig (Peter- } \\
\text { head) }\end{array}$ \\
\hline 4 & A'Leth Eile & Cailean T. MacCoinnich & 1971 & $\begin{array}{l}\text { Roinn nan Cànan Ceil- } \\
\text { teach, Oilthigh Ghlaschu }\end{array}$ \\
\hline 5 & Gainmheach an Fhàsaich & Màiri NicGillEathain & 1971 & Club Leabhar, Inbhir Nis \\
\hline 6 & Creach Mhòr nam Fiadh & Tormod Domhnallach & 1973 & $\begin{array}{l}\text { Stornoway Gazette Ltd, } \\
\text { Steòrnabhagh }\end{array}$ \\
\hline 7 & An t-Aonaran & Iain Mac a Ghobhainn & 1976 & Oilthigh Ghlaschu \\
\hline 8 & Deireadh an Fhoghair & Tormod Caimbeul & 1979 & U \& R Chambers, \\
\hline 9 & Na Speuclairean Dubha & Iain Mac a Ghobhainn & 1989 & Gairm, Glaschu \\
\hline 10 & Am Fear Meadhanach & Alasdair Caimbeul & 1992 & $\begin{array}{l}\text { Druim Fraoich, Conon } \\
\text { Bridge }\end{array}$ \\
\hline 11 & An Sgàineadh & $\begin{array}{l}\text { Tormod Calum Dòmhnal- } \\
\text { lach }\end{array}$ & 1993 & Acair, Steòrnobhagh \\
\hline 12 & Cùnnantan & Tormod MacGill-Eain & 1996 & Clò Loch Abair, Glaschu \\
\hline 13 & Keíno & Tormod MacGill-Eain & 1998 & Clò Loch Abair, Glaschu \\
\hline 14 & $\begin{array}{l}\text { An Oidhche mus do Sheòl } \\
\text { Sinn }\end{array}$ & Aonghas Pàdraig Caimbeul & 2003 & Clàr, Inbhir Nis \\
\hline 15 & $\begin{array}{l}\text { Là a' Dèanamh Sgèil } \\
\text { do Là }\end{array}$ & Aonghas Pàdraig Caimbeul & 2004 & Clàr, Inbhir Nis \\
\hline 16 & Tocasaid 'Ain Tuirc & Donnchadh MacGillIosa & 2004 & Clàr, Inbhir Nis \\
\hline 17 & Dacha Mo Ghaoil & Tormod MacGill-Eain & 2005 & Clàr, Inbhir Nis \\
\hline 18 & Na Klondykers & Iain F. MacLeòid & 2005 & Clàr, Inbhir Nis \\
\hline 19 & Gymnippers Diciadain & Màrtainn Mac an T-saoir & 2005 & Clàr, Inbhir Nis \\
\hline 20 & Am Miseanaraidh & Iain Mac a Ghobhainn & 2005 & Clàr, Inbhir Nis \\
\hline 21 & Dileas Donn & Norma NicLeòid & 2006 & Clàr, Inbhir Nis \\
\hline 22 & Shrapnel & Tormod Caimbeul & 2006 & Clàr, Inbhir Nis \\
\hline 23 & An Taigh Samhraidh & Aonghas Pàdraig Caimbeul & 2007 & Clàr, Inbhir Nis \\
\hline 24 & Cleas Sgàthain & Màiri Anna NicDhòmhnaill & 2008 & Clàr, Inbhir Nis \\
\hline 25 & Slaightearan & Tormod MacGill-Eain & 2008 & Clàr, Inbhir Nis \\
\hline
\end{tabular}




\section{Rusi na Zapadnim otocima}

Sažetak

Premda Rusi nisu bili tako aktivni osvajači kao mnoge druge imperijalističke nacije, ipak ih nalazimo na mjestima na kojima ih najmanje očekujemo. Veze između Rusije i Škotske prilično su slabe, pa ipak, ruska je prisutnost opipljiva u nekoliko suvremenih škotskih gaelskih romana. Od svih modernih književnih žanrova gaelski je roman najslabije razvijen, ali je u proteklom desetljeću doživio obilan razvoj. Gaelski je roman tradicionalno govorio o nepodnošljivom životu u strogo kontroliranoj prezbiterijanskoj zajednici i o želji za slobodom kao posljedici takvog života. Noviji romani govore o raspadu lokalne zajednice i o prodoru modernog svijeta. U nekoliko slučajeva stranci koji probijaju granice lokalne organske zajednice bili su Rusi. To se pogotovo vidi u romanima Dacha Mo Ghaoil Tormoda Macgilleaina i Na Klondkyers Iaina F. Macleoida. Ovi su romani zanimljiv slučaj pronalaska "drugoga" da bi se provjerila vrijednost sebe i privlačna studija susreta fikcije sa stereotipima. U ovom radu raspravlja se o tim "nezgodnim" Rusima koji se upliću u tradicionalan način života takozvane romantične Škotske.

Ključne riječi: škotski gaelski, gaelski roman, Rusi, stranci

Key words: Scottish Gaelic, Gaelic novel, Russians, outsiders 